\title{
Transformation of the national country studies in the eastern of Ukraine
}

\author{
O. V. Chala \\ Luhansk Taras Shevchenko National University \\ Corresponding author. E-mail: andreychaliy13@mail.com
}

Paper received 24.04.19; Accepted for publication 06.05.19.

\section{https://doi.org/10.31174/SEND-PP2019-197VII79-02}

\begin{abstract}
With the help of the term "transformation" the alterations experienced by the national country studies in the eastern part of Ukraine have been highlighted. The problem requires a comprehensive analysis and cooperation of local country studies and educators, using modern information and communication technologies. An attempt has been made to determine the prospects of regional studies in the context of modern socio-cultural situation and, most importantly, to identify its capabilities as a science and as a field of human activity in connection with the development and implementation of cultural policy, primarily regional. The article also highlights modern landmarks in the education of Ukraine where relevant priorities are closely intertwined with the tasks facing regional studies. These benefits have been reflected in the Law of Ukraine "On Education" and the National Doctrine on Education Development. It has been noted that the system of national education is a significant component in the dissemination of local country studies knowledge.
\end{abstract} ies.

Keywords: transformation, country studies, phenomenon of regional country studies, local country studies fund, ecological country stud-

The development of the country in scientific, economic, cultural aspects depends on the level of education of the population. Modern Ukrainian education is aimed at increasing the efficiency of educational process in order to form a competent personality able not only to acquire knowledge and skills, but also to respect the traditions and customs of one's and other people, to find common language with representatives of different cultures. These priorities are reflected in the main documents on education, in particular, in the recently adopted Law of Ukraine "On Education" providing opportunities for the promotion of competency education. An attempt to create a brand new education system will provide conditions for education for all categories of the population of Ukraine, comprehensive human development, and will contribute to a significant increase in the intellectual, cultural, spiritual and moral potential of society in general and personality in particular. The National Doctrine on the Development of Education states that education is aimed at ensuring comprehensive development of an individual through education and upbringing based on the unity of these two concepts, universal values and principles of science, multiculturalism, systemicity, integrity on the basis of humanism, democracy, civic consciousness, mutual respect between nations and people in the interests of a human being, family, society, state. To properly solve the problems related to the restructuring of education, it is necessary to consider, synthesize and comprehend the peculiarities of functioning of all its components, including country studies. It is precisely the system of national education that makes a significant contribution to the dissemination of local country studies knowledge. The tasks, which country studies are faced with, overlap with educational priorities, in particular, raising of citizens' sense of national consciousness, deep respect for the history, culture, language, traditions of the Ukrainian people, as well as other nations connected with them by their destiny, all-round assistance the development of independent Ukraine, the revival of spirituality and historical memory in society [5].

The problem of interconnection of country studies and education is quite topical. Ukrainian scientists L.Haida, O.Demifenko, M.Dmitriyenko, S.Zakharov, M.Krachilo, V.Prokopchuk, P.Tronko, F.Shevchenko and others paid particular attention to it in their works [10; 7]. This problem has long been in the centre of active discussion at scientific and practical conferences of scholars, ethnographers and educators [6].
At present, however, the changes, which country studies in the Eastern part of Ukraine have undergone, have not been properly investigated. This fact requires a thorough analysis and cooperation of ethnographers and educators, using the latest information and communication technologies. Therefore, the state of development of modern country studies in the eastern region of Ukraine, as well as the system of national education as a whole comprise a burning issue. In this regard the aim of our article is to examine and define the essence of the transformational processes of national country studies in the Eastern part of Ukraine.

Modern civilization-related changing processes in the state can be characterized by the term "transformation", which possesses its own semantic load. Transformation means "substantial structural change of the system, which is being transformed by means of changing the relationships, relations, mediations of organization and functions of initial form-formation. Transformation is a typical transitional process of social evolution" [17]. The whole complexity of transformation processes consists in the need to take into account the old and to elaborate new models of social development.

The questions of educational transformation, systemic transformation in education have been raised in academic works by V.Andrushchenko, L.Berezivska, A.Boyko, A.Vasilyuk, K.Garaschuk, V.Kremen, V.Lutai, M.Romanenko, A.Sbrueva, M.Fullan, N.Schubelka and others.

The events that took place in the country led to the transformation of country studies in the Eastern part of Ukraine. This has resulted in the growth of national selfconsciousness, the revival of spiritual culture, the strengthening of local self-awareness and led to the enhancement of local country studies activities in the region.

The future of modern society is determined today by the fact what will be laid in the upbringing of the younger generation. Therefore, an important role in the spiritual and moral formation of young people belongs to country studies. It opens up wide opportunities for the formation of a personality, civic position. Through the study of the past and understanding of the present citizens perceive themselves as part of a country that can influence its development. The study and promotion of knowledge about the native land contribute to the national and patriotic upbringing of youth.

Today this branch of knowledge is undergoing a process of looking for new forms, setting up priority tasks. Country studies education acquires a pronounced socio-political 
character, especially in connection with the growing interest in the past of certain territories, as well as in the view of aggravation of national, economic and environmental problems. Many representatives of scientific circles, ecologists, economists, educators, members of public movements spoke about "small Motherland".

Country studies is a compelling example of interdisciplinary knowledge, which includes geographical, historical, biographical, demographic, environmental, sociological, museum studies, library, literary aspects.

According to S.Farlenkova country studies is a cultural, historical-anthropological and socio-psychological phenomenon with deep historical roots. It is characteristic of all countries and people. Performing a lot of functions, including one of the most important - information, country studies allow to accumulate, store and transmit from generation to generation, from century to century considerable amount of special knowledge [16].

Particular importance should be attached to the process of laying down the foundations for this science since country studies has its own genesis and development.

Today to understand the phenomenon of country studies it is important also to view it in terms of socio-cultural approach. Country studies as a sociocultural phenomenon has almost a century-long history. Modeling qualitative characteristics of the development of country studies (as a socio-cultural phenomenon) in different years, one can analyze separate components of local history system, can predict its development. Therefore, this approach in analyzing the material on the history of country studies allows to identify effective mechanisms for the formation of its complex system, its functional and structural features at different stages of development on the background of sociocultural changes taking place in Ukraine. As a result, a more objective definition of the prospects of country studies in the context of today's socio-cultural situation and, most importantly, the identification of its capabilities as a science and as a field of human activity in connection with the development and implementation of cultural policy, especially regional.

Academician D. Likhachev was afraid of the liberation of a modern man from his own cultural roots, he wrote about the need for a "spiritual settlement", called for the creation of a special science - the "ecology of culture". It can be assumed that under the "spiritual sediment" the scientist meant internal maturity. Therefore, to educate this maturity the most important role should be given to local country studies, which was highly valued. But life, which is rapidly being updated, creates fundamentally new conditions for Ukrainians and affirms new cultural values - a huge stratum of culture has gone to the past. But the past retains its attractiveness, it remains to be of interest as a cultural value, as recent but nevertheless gone-by past. The important thing about the idea of country studies is that the subject of the study is not only the past, but also the present and even, to a certaine degree, the future [5].

In modern realities, the educational and unifying potential of the history of the Motherland and the native land becomes especially significant, playing an important role in the multiplication and diversification of the functions of country studies.

With the onset of hostilities in the Donbas, the Luhansk Regional Organization of the National Union of Country Studies Experts of Ukraine was forced to evacuate to the city of Starobilsk, Luhansk region. It took a fair amount of time to rebuild the Union headquarteres, to change the address officially. It was quite difficult to gather the Conference of the organization (the main governing body), since its members dispersed throughout Ukraine, some are abroad. I had to change the majority of the governing body of the Union. As the chairman of the organization Vitalii S. Kurylo was re-elected, doctor of pedagogical sciences, professor, academician of the National Academy of Pedagogical Sciences of Ukraine. It is indicative that the organization has been settled on the basis of the Luhansk Taras Shevchenko National University, which has also been evacuated to Starobelsk and despite the difficulties has confirmed the status of the educational and cultural center of the East of Ukraine after evacuation. Currently, the work of the Luhansk Regional Organization of the National Union of Country Studies is being complicated by the occupation of the region, the presence of many settlements under the control of the terrorist organization "LNR". One of the priority tasks of the Luhansk Regional Organization of the National Union of Country Studies is to disseminate the information about the past and present-day of Luhansk region in the media. In the conditions of information aggression it is extremely important to focus the attention of society on topical issues of the history of the region, to provide objective information in the popular science-style. In particular, a regional scientific and practical conference "Luhansk region: country studies exploration", which took place in Luhansk Taras Shevchenko National University and became a real cultural event for Luhansk region as a whole and the city of Starobilsk in particular. Lecturers at HEI are members of many scientific societies, among them the National Union of Local Linguists of Ukraine - a voluntary association of professional researchers and chroniclers of their native land. Educators from different regions of Ukraine, as well as students of Luhansk Taras Shevchenko National University took part in the scientific event. Scientists from Kyiv, KamyanetsPodilskyi and various regions of Luhansk Oblast sent their works. Until the tragic events of 2014 and the relocation of Luhansk Regional Organization of the National Union of Country Studies to Starobelsk such events were traditional and did not cause excessive agitation. Thanks to the efforts of the members of the Union during the years of forced evacuation the traditional conferences that were held annually before the beginning of hostilities have been restored.

Thus, today the restoration of the traditions of holding such events testifies to the revival of cultural, in particular, regional history in the region. Luhans regionologists contributed to the publication of the multi-volume Encyclopedia of Modern Ukraine (ECU), the first multi-volume publication that comprehensively presents a holistic multifaceted image of Ukraine in the XX - XXI centuries in individuals, institutions and concepts. The publication covers all spheres of the country's existence: from geographical position, nature, history, political system, economy and industry, science, culture, art, literature to sports and youth subculture.

Resources created in the process of country studies explorations are strategic resources. They, on the contrary, eventually become more valuable for those who investigate the region. Today the role of libraries in local linguistic information can not be overemphasized: from those institutions and organizations engaged in country studying, the libraries themselves preserve information country studying resources, sources of country studying information for the population, while remaining at the same time the most 
accessible institutions for different categories of users. The basis of all local country studying activity of the library is the local lore fund - this is the ordering of the set of documented information on the land. It is used by readers and librarians for different purposes: to satisfy the country studying requests of readers; to provide bibliographic information on regional studies; to identify the necessary materials in preparing and compiling manuals, collections, almanacs and other editions of local country studying content; to organize and host country studying events, etc. Without a full-fledged knowledge-based fund, a serious linguistic work of the library is impossible.

An increase in the number of country studying editions and, in particular, the most operational part of it publications in newspapers and magazines as a response to the growing need of society in country studying information. On the pages of periodicals materials on country styding appear regularly, reflecting various aspects of it: history and current state, culture, economy, biographies of distinguished personalities. An important part of the local history periodicals publications on the same subject for children have become. It has been well said in a speech dedicated to the role of libraries in the modern world by A. Hachev: "the library is the repository of all-man's memory, the space of meeting with the inheritance, the center of universal knowledge - the key link of the noosphere. Among civilization, which make choices in favor of genuine, not artificial values, it plays a leading role. Such civilization is aware of its planetary role and responsibility and, therefore, appreciates knowledge, memory, continuity [2].

At present Luhansk Oblast O. Horkyii Universal Scientific Library (Good library) starting from 2015, after long wanderings and lack of elementary working conditions has moved to the city of Starobilsk. It represents an unbundled, completely new, free space without borders. The library does not have such a giant space which it possessed before military actions in Luhansk, its fund does not comprise dozens of thousands of books, as it was earlier. It does not have a large workforce (146 employees at the beginning of 2014). But it has a young, creative, brave team filled with new ideas and a huge desire to break the system of library business, to destroy forever awkward stamps about libraries. Now the library has about 6,000 absolutely new editions of literature of various kinds. Today, this institution is absolutely new seeking to make library work as close to the world standards as possible, boldly embody the boisterous ideas, breaking old stereotypes.

In the context of the military conflict that took place in the region (and taking into account the information warfare) Luhansk Regional Office of Ukrainian Library Association positions itself as a public organization that guarantees the provision of objective and truthful information by libraries to people of the region, and its work is based on the principles of preserving integrity of the state.

Historical and cultural heritage gathered by millions of people through many centuries, who are interested in preserving it for future generations, is contained in archives. Archive is an institution dealing with the storage and description of various documents of the past: manuscripts, photographs, maps.

The National Archival Fund of Ukraine is a collection of all archives, archival funds and collections, documentary monuments, documents of special historical, scientific, social, economic, political or cultural significance recognized in the manner established by law taking into account national values.

The State Archive of Luhansk Oblast is the main archival institution of the region. In 2014 the archive without documents was transferred to the city of Severodonetsk, though its funds remained in the occupied Luhansk. The network of archival institutions subordinated to the State Archive of the region, as of 01.11.2016, includes 12 archival departments of regional state administrations and 3 archival departments of city councils, 14 labor archives. Labor archives - archival institutions established by local executive authorities and local self-government bodies for the sake of the centralized temporary storage of archival documents accumulated in the process of documenting official, labor or other legal relationships of legal entities and individuals on the respective territory (district, city), and other archival documents not belonging to the National Archival Fund. However, during 2016 the network of archival institutions underwent some changes. The status of legal entities of public law was given to 10 archival institutions of regional state administrations. 17 institutions at villages of StanychnoLuhansk district were united in Institution "United Labor Archive of Stanichno-Luhansk District". It has been succeeded to solve a number of logistics issues: additional premises with total area of $353.6 \mathrm{~m}^{2}$ were obtained, the length of shelving equipment increased by $873 \mathrm{~m}$, and the works started on repairing in the archival department of the Svatovo District State Administration. Specialists of the State Archive and archival institutions of the region carried out 116 inspections of documents' and archival offices at local enterprises, institutions, organizations - sources of compiling and work of archival institutions of the region. 28 workshops and four sessions of the Scientific and Methodological Council of the State Archive were conducted, 64 exhibits of documents were organized. At present the work started on preparing for modern equipment scanning of archival documents and three funds have already been digitized.

The histories of families pass from the eldest to the younger - from generation to generation. And the history of the land is transferred to its inhabitants with the help of local country studying museums. In the midst of military actions in 2015 the Luhansk Regional Museum of Local Lore as one of the main cultural and educational institutions of the region was to be evacuated and relocated to the territory under the control of Ukraine. The task seemed not easy because the museum can not "be moved". Nevertheless, it was translated and re-registered on the basis of the Starobelsk District Museum, which is located in the building of the Demenkivskyi Craft School - the building of the XIX century $(1855-1858)$ - that situated in this place for almost two centuries. In such a way, the active restoration of the museum started from the beginning. All property and exhibits remained on the uncontrolled area. A tremendous amount of work was done to replenish the collection of museum exhibits, which already had Starobilsk Museum, rare archaeological and natural exhibits. The staff of the institution decided not to wait till the end of hostilities, but to write the history of the war today. Therefore the exhibition hall dedicated to the events in the Donbass was opened. Exhibits connected with the anti-terrorist operation are a history page that has not yet ended. The collection consists of unique things that come from the advanced. It is ammunition a handwritten collection of poetry, a rose, made from fragments of military shells as a symbol of regeneration after 
devastation. The new exposition "My Ukrainian Wreckers" was held at Starobelsk at the initiative of the museum, along with labor collectives and military personnel. New author's developments of the museum appeared: "Persons of the Ukrainian Revolution", "The Memory of the Heavenly Hundred", "Work of the Central Council in the language of documents". The Luhansk Regional Museum works as a scientific and methodological center for museum studies in the region, and starting from 2016 the work of all thirteen museums of the region is coordinated from here.

At present Ukraine suffered enormous human, territorial, economic losses. Communal, social and industrial infrastructure has undergone enormous destruction on the territory of Donbass [10]. Local historians themselves should participate directly in the research and identification of resources at the local level that can be used in the public interest in order to adapt the economy in the context of the ATO and a temporary loss of part of Donbass. Today it is necessary to focus on the critical ecological situation in Luhansk and Donetsk regions. The report of the OSCE Project Coordinator in Ukraine and the Ministry of Environment and Natural Resources of Ukraine states that $17 \%$ of forests and $24 \%$ of steppes in the region suffered during the armed conflict in Donbass. It is impossible to estimate the situation on the territory non-controlled by Ukraine because of the lack of access. This leads to new challenges in regional studies. Therefore, it should be noted that ecological regional studies is quite a new direction in modern pedagogy, the importance of which is explained by today's critical state of the environment in the eastern part of Ukraine. At present, social, economic and moral atmosphere is complicated, requires profound rethinking of educational programs and reflection in the educational process on issues of environmental responsibility of a human being for the consequences of their actions to nature. Ecological education begins with the attentive view of each of us on the world around us, with the desire to deeper understand this world, to understand one's place in it and one's responsibility for it. The formation of environmental responsibility should become the ethical norm that forms ecological consciousness.

Linguists argue that education is a determining factor in socio-economic, cultural, scientific and political life of a society, life that should have a humanistic character and be based on the cultural and historical values of the Ukrainian people, their traditions and spirituality. National education should be placed among the main priorities of the educational field, education with its integral part in the form of regional studies, aimed at involving younger generation in the study of history and culture of native land, formation of a conscious citizen of state, upbringing of love for their native land.

An important task is the active use of the broad potential of country studies in national education. The main function of the latter is determined by the need to attract public attention to local country studies, the formation of national consciousness of citizens, the intensification of scientific research in the field of historical and cultural achievements, the preservation and enhancement of the spiritual treasures of native land, the growing interest of people in the history of their region, their Motherland.

Thus, the role of country studies in the life of modern society is growing, society, which is also undergoing a stage of reform, a rapid transformation of social groups. During such periods country studies performs a dual function. On the one hand, it is intended to investigate a separate edge in order to facilitate its transformation on the basis of specific knowledge of regional conditions and opportunities. On the other hand, country studies serves as an adaptively stabilizing factor in an unstable society.

\section{REFERENCES}

1. Haida L. Formation of the normative and legal framework of museums in educational institutions of Ukraine // Krajinoznavstvo. №3 - №, 2011. - P. 49-56.

2. Hacheva A. Speech at the ceremony of summarizing the II AllRussian competition "The Librarian of the Year" / A. Hacheva // Russian Library Association [Electronic Resourse]. - Access: www.rba.ru/content/news/vid_news_str.php?id=3799.

3. M. Dmytriienko. Specific historical disciplines: the significance of their research for the development of historical regional studies / M. Dmytriienko // Topical Issues of studying regional studies in high school. - Kirovograd, 1990. - P. 13-17.

4. S. Zakharov. Functions, stages, stages of geographical country studies / S. Zakharov // Geography and the basics of economy at school. - 1999. - №3. - P. 38-39.

5. D. Likhachov. Country Studies as a science and as an activity // Russian Culture. - M.: Arts,2000. - P.159-173.

6. D. Likhachov. Letters about the good and the beautiful. - M.: Science, 1989. - $231 \mathrm{p}$.

7. V. Nikolskii. Organization of local country studies' work in the Donbas in the 1920's. // Materials of the Vth the Whole Ukrainian Scientific Conference. - Kamjanets-Podilskii, 1991. -P.41-42.

8. About the National Doctrine of Education Development: Adopted by the Decree of the President of Ukraine dated 17.04.02, № 347 / 2002 // Official Visnyk of Ukraine. - 2002. - № 16. - 860 p.

9. On Education. Law of Ukraine dated 05.09.17 № 2145-VIII. (Information Bullitin of Verkhovna Rada, 2014, № 37-38, art.2004). (with changes adopted in 2017, № 33, art.360 № 2145VIII on 05.09.2017, Information Bullitin of Verkhovna Rada, 2017, № 38-39, art.380).

10. Public report of the Head of Donetsk Regional State Administration, Head of the Regional Military-Civil

Administration $\quad$ of
(http://www.slideshare.net/donpressa/ss-63342943.

11. O. Reent. Patriarch of Ukrainian Local History / Oleksandr Reent // What will we leave to our descendants? - K.: Institute of History of Ukraine, NAS of Ukraine, 2008. - P. 48-59.

12. Statute of the All-Ukrainian Union of Country Studies. K.,1990.P. 2.

13. P. Tronko. Historical Local History: A Step in a New Millennium (Experience, Problems, Perspectives) / Petro Tronko. - Institute of History of Ukraine, NAS of Ukraine, 2000. - 272 c.

14. P. Tronko. Country studies in the revival of spirituality and culture. Experience. Problems Perspectives / P. Tronko; Introductory Word and Editing by F. Shevchenko. - K.: Homeland, 1994. $-108 \mathrm{p}$

15. P. Tronko. 70th anniversary of the Ukrainian Committee on Local Country Studies and the task of further development of research on the history of the native land // VII Whole-Ukrainian Scientific Conference „Historical Country Studies in Ukraine: Traditions and Present Day. Part.1. -K.: Homeland, 1995.-P. 6-7.

16. S. Farlenkova. Centers of local country studies information on the basis of regional libraries as a resource for preserving the polyethnic culture of the indigenous minorities of the north of the Yamalo-Nenets Autonomous District / S. Farlenkova [Electronic Resourse] URL: http://www.gpntb.ru/win/interevents/crimea2005/ disk/68.pdf.

17. Y. Sheyhorodskii. The concept of "Transformation" as a tool for analyzing social change / Y. Sheyhorodskii // Education of the region. Politology. Psychology.Communications. - 2010. - № 4. - P. $52-58$.

18. F. Shevchenko. The connection of historical country studies with special historical disciplines//Abstracts of the Second Ukrainian Republican Conference on Historical Local History. K., 1982.P.4. 